\title{
TEST AND DEMONSTRATION GARRIAGE FOR TRACTOR-POWERED IMPLEMENTS
}

\author{
ERKKI H. OKSANEN \\ University of Helsinki, Departm. Agric. Economics, Subdiv. Agric. Engineering
}

Received May 8, 1968

The instruction given to the agricultural students at the Faculty of Agriculture and Forestry, University of Helsinki, includes, among other things, a course in Farm Machinery with machine demonstrations in which the construction, use, adjustment, and maintenance of a machine are briefly reviewed in the classroom or in the machine hall. For this purpose tractor-powered implements were attached to a tractor, which, however, caused noise and exhaust smoke and dust that disturbed the instruction. To avoid these, a movable test and demonstration carriage was constructed mainly from components purchased from a car wrecker or received as donations (Figure 1).

The carriage has a chassis built from tubing and different profiles of steel. It is supported by two rear wheels and one front wheel. On the chassis there is a $3 \mathrm{~kW}$, three phase electric motor with a speed of 1400 revolutions per minute (RPM) and a push-button start. Two car gear boxes, both with three forward speeds and one reverse, are placed side by side and transversally on the chassis. The primary gear box is coupled to the electric motor, and the secondary one is driven from it by V-belts. The power of the electric motor is transmitted by the gear boxes to a car rear axle behind the secondary gear box. A power-take-off shaft (PTO) is welded to the half axle pointing rearwards. Due to differentials, the PTO turns when the other half axle is braked. Above the short-cut rear axle there is a tractor hydraulic three-point lift from the VALMET 359 D-tractor. The pump of the lift is run by the electric motor through a V-belt.

The power transmission was calculated so that the highest speed of the PTO is, in accordance with the international standards, $540 \pm 10$ RPM. The lowest speed is 30 RPM. There are 16 different gear combinations, which give the PTO the speeds presented in Table 1. 


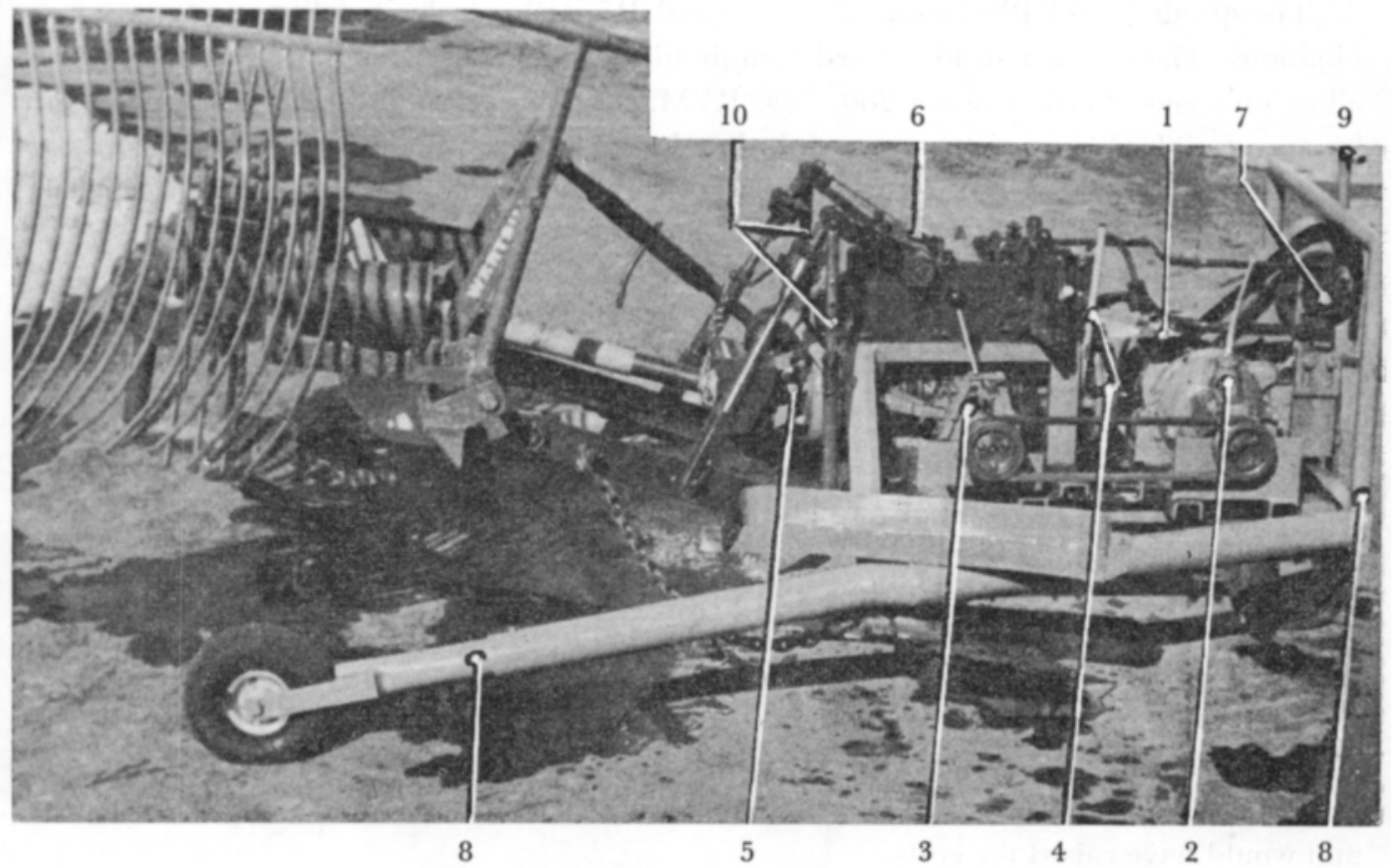

Figure 1. Test and demonstration carriage for tractor-powered implements. A $3 \mathrm{~kW}$ electric motor (1) runs the primary gear box (2). This transmits the power to the secondary gear box (3) by V-belts (shield removed) which also act as a safety clutch. The secondary gear box is taken from a car, where the rear axle with the differentials has been behind the gear box. The rear axle halves were cut shorter during the construction. The forward pointing half of the axle can be locked to a stand-still with a hand brake (4), after which the PTO (5; covered partly with a shield) welded to the half pointing backwards will rotate at speeds presented in Table 1. The hydraulic lift (6) was donated by the VALMET tractor factory. The pump (7) of the lift is powered by a V-belt from the shaft between the electric motor and the primary gear box. All components are fitted on a wheel chassis (8) which is moved by pulling the drawbar (9) attached to the axle of the front wheel. The rear wheels are at the end of a telescopic tubular chassis and may be pulled further out if needed. A potato spinner is attached to the carriage in the picture. The implement stays in a raised position by telescopic supports (10) attached on the chassis. The chassis and power transimission parts are painted grey except for the gear shift levers and the brake lever which are yellow. The complete hydraulic lift is red in colour.

Table 1. The PTO speeds of the test and demonstration carriage for tractor-powered implements on different gear combinations. The minus mark preceeding the number indicates that the direction of rotation is counterclockwise.

\begin{tabular}{|c|c|c|c|c|}
\hline $\begin{array}{l}\text { Primary } \\
\text { gear }\end{array}$ & 1 & $\begin{array}{c}\mathrm{Sec} \text { e n d a r y } \\
2\end{array}$ & $\begin{array}{l}\text { g e a } r \\
3\end{array}$ & Reverse \\
\hline 1 & 52 & 100 & 180 & -40 \\
\hline 2 & 90 & 178 & 315 & -92 \\
\hline 3 & 162 & 315 & 550 & -122 \\
\hline Reverse & -40 & -75 & -138 & 30 \\
\hline
\end{tabular}


The speeds of 40 RPM counterclockwise and 315 RPM clockwise fall on two gear combinations. The number of low speed combinations is sufficient, but the gear boxes used allow only one speed between 200-500 RPM. So far this has not caused any trouble, because mainly slow motions are used during demonstrations. Lower speed than the smallest fixed one ( 30 RPM) for the PTO is obtained by letting the brake slip which keeps the other half axle in a stand-still.

The device has functioned well. The PTO has been able to power at full speed all unloaded PTO-driven tractor implements and machines attached to it. No performance measurements have been made so far, but since the power source selected is a $3.0 \mathrm{~kW}$ or $(3 \times 1.36=) 4.08 \mathrm{HP}$ (horse power) electric motor, and, moreover, the electric motors are known for their overloading characteristics for shorter periods, there should be ample power even for large machines. For instance, a pull-type combine harvester with a 5 feet cut requires unloaded, according to measurements done by PEDERSEN (1963, p. 13), 5. 36. $8 \mathrm{HP}$. This, however, would be too much for the device presented, but the use of PTO speeds lower than 550 RPM would make it possible to run the combine, as its power requirement decreases with a diminishing RPM.

The lack of a clutch between the electric motor and the primary gear box may be regarded as a disadvantage as the electric motor has to be stopped when changing to another gear combination. The fitting of a clutch would, however, have been technically difficult and would have raised the costs.

When tractor-powered implements for 1000 RPM become more common, a PTO for this speed may be added to the device, or the present speed may be altered by changing the V-belt pulleys. At the same time, to eliminate the belt slip, the belt power transmission between the gear boxes may be replaced by chains. In this case the PTO driven shaft or one of the chain sprockets must be equipped with an overload clutch.

The use of the carriage constructed will not be limited to machine demonstrations only and it will later be used for test and research purposes.

\section{$S u m$ mary}

A movable test and demonstration carriage for tractor-powered implements (Figure 1) was constructed mainly for machine demonstrations to the agricultural students at the University of Helsinki. The carriage is provided with a PTO-shaft run by a $3 \mathrm{~kW}$ electric motor trough two car gear boxes. The PTO-speeds on different gear combinations are $30-550$ RPM (Table 1). For attachment of the implements, the carriage is also provided with a 3-point hydraulic lift, run by the electric motor.

\section{REFERENCES}

Pedersen, T. T. 1963. Effektbehov ved mejetaerskning af korn. Kgl. Veter. Landbohöjsk. Afd. Landbr. maskiner. Medd. 7:1-39. 


\title{
SELOSTUS
}

\section{TRAKTORITYÖKONEIDEN KOKEILU- JA ESITTELYLAITE}

\author{
ERKKI H. OKSANEN
}

Helsingin yliopiston Maanviljelystalouden laitos/Maatalouden työtekniikka

Maatalousylioppilaiden opetukseen Helsingin Yliopistossa kuuluu konedemonstraatioita, joiden aikana traktorin käyttö aiheuttaa opetusta häiritsevää melua, pakokaasua ja pölyä. Näiden välttämiseksi rakennettiin kuvassa 1 esitetty laite, jota on nimitetty msähkötraktoriksi». Se antaa käyttövoiman traktorityökoneille ja siihen ne myös voidaan kiinnittää kuten traktorin nostolaitteisiin.

Pyöräalustaiselle rungolle sijoitettu $3 \mathrm{~kW}$ sähkömoottori käyttää kahden autonvaihteiston välityksellä jälkimmäisen perässä olevaa auton taka-akselia. Sen toista akselinpuoliskoa jarrutettaessa pyörii toinen, taaksepäin osoittava, jonka päähän on hitsattu voimanottoakseli, eri vaihdeyhdistelmillä taulukossa 1 esitetyillä nopeuksilla. Taka-akselin päällä on traktorin nostolaite, jonka pumppu saa käyttövoiman sähkömoottorin akselilta.

Laite on pikku puutteellisuuksista huolimatta toiminut hyvin. Sitä tullaan myöhemmin käyttämään myös tutkimustarkoituksiin. 